\title{
Cenozoic-Recent tectonics and uplift in the Greater Caucasus: a perspective from Azerbaijan
}

\author{
JON MOSAR ${ }^{1 *}$, TALAT KANGARLI ${ }^{2}$, MARTIN BOCHUD ${ }^{1}$, ULRICH A. GLASMACHER ${ }^{3}$, \\ ANNICK RAST ${ }^{1}$, MARIE-FRANCOISE BRUNET ${ }^{4} \&$ MARC SOSSON $^{5}$ \\ ${ }^{1}$ Département de Géosciences - Sciences de la Terre, Université de Fribourg, \\ Chemin du Musée 6, CH-1700 Fribourg, Switzerland \\ ${ }^{2}$ Geology Institute of Azerbaijan, National Academy of Sciences, H. Javid av. 29A, \\ Baku AZ1143, Azerbaijan \\ ${ }^{3}$ Institute of Earth Sciences, Im Neuenheimer Feld 234, 69120 Heidelberg, Germany \\ ${ }^{4}$ UPMC Univ Paris06-CNRS-INSU, UMR Institut des Sciences de la Terre Paris Case 129, \\ 4 place Jussieu, 75005 Paris, France \\ ${ }^{5}$ CNRS -GeoSciences Azur, UMR 6526, 250 Rue Albert Einstein - Sophia Antipolis, \\ 06560 Valbonne, France \\ *Corresponding author (e-mail: jon.mosar@unifr.ch)
}

\begin{abstract}
The Greater Caucasus is Europe's highest mountain belt and results from the inversion of the Greater Caucasus back-arc-type basin due to the collision of Arabia and Eurasia. The orogenic processes that led to the present mountain chain started in the Early Cenozoic, accelerated during the Plio-Pleistocene, and are still active as shown from present GPS studies and earthquake distribution. The Greater Caucasus is a doubly verging fold-and-thrust belt, with a pro- and a retro wedge actively propagating into the foreland sedimentary basin of the Kura to the south and the Terek to the north, respectively. Based on tectonic geomorphology - active and abandoned thrust fronts - the mountain range can be subdivided into several zones with different uplift amounts and rates with very heterogeneous strain partitioning. The central part of the mountain range - defined by the Main Caucasus Thrust to the south and backthrusts to the north - forms a triangular-shape zone showing the highest uplift and fastest rates, and is due to thrusting over a steep tectonic ramp system at depth. The meridional orogenic in front of the Greater Caucasus in Azerbaijan lies at the foothills of the Lesser Caucasus, to the south of the Kura foreland basin.
\end{abstract}

The Caucasus orogen lies at Europe's cross-road with Asia and Arabia, and is one of the world's outstanding mountain ranges (Fig. 1). It is Europe's highest mountain range with Mount Elbrus culminating at $5642 \mathrm{~m}$ a.s.l. in the western Greater Caucasus. It consists of the Greater Caucasus (GC), intramontane basins (Kura-Kartli-Rioni; c. $200 \mathrm{~m}$ elevation) and the Lesser Caucasus. North of the Greater Caucasus the deep sedimentary Terek and Kuban foreland basin $(>6000 \mathrm{~m}$ thick; up to 1600 m elevation) form the transition to the Scythian platform. NNW of Mount Elbrus, the Stavropol 'high' forms a basement uplift, and in the east the northern slope is formed by the Dagestan foreland fold-and-thrust belt. The southern Greater Caucasus foreland, SW of Tbilisi is one of the world's earliest sites of human society with $1.8 \mathrm{Ma}$ old hominoid remains of Dmanisi (Georgia) (Lordkipanidze et al. 2007). The Lesser Caucasus with lower topography $(c .3000 \mathrm{~m})$, is a zone of important volcanic and seismic activity. In the east and west, the Caucasus topography is bound by two very deep sedimentary basins, the South Caspian Sea and the Black Sea, hosting some of the world's largest oil and gas provinces.

The Caucasus orogen is caused by the north directed movement of the Arabian plate squeezing a Jurassic to Early Palaeogene subduction related volcanic arc (Lesser Caucasus) as well as Jurassic to Pliocene marine sedimentary rocks and sediments (northern Lesser Caucasus, substratum of KuraKartli Basins and Greater Caucasus Basin) towards the Scythian plate (Gamkrelidze 1986; Nikishin et al. 2001; Stampfli et al. 2001; Popov et al. 2004; Hafkenscheid et al. 2006; Kazmin \& Tikhonova 2006; Sosson et al. 2010). Recent plate tectonic models and GPS-based convergence rates (Gamkrelidze \& Kuloshvili 1998; Vernant et al. 2004; Reilinger et al. 2006; Kadirov et al. 2008) suggest a moderate anticlockwise rotational 


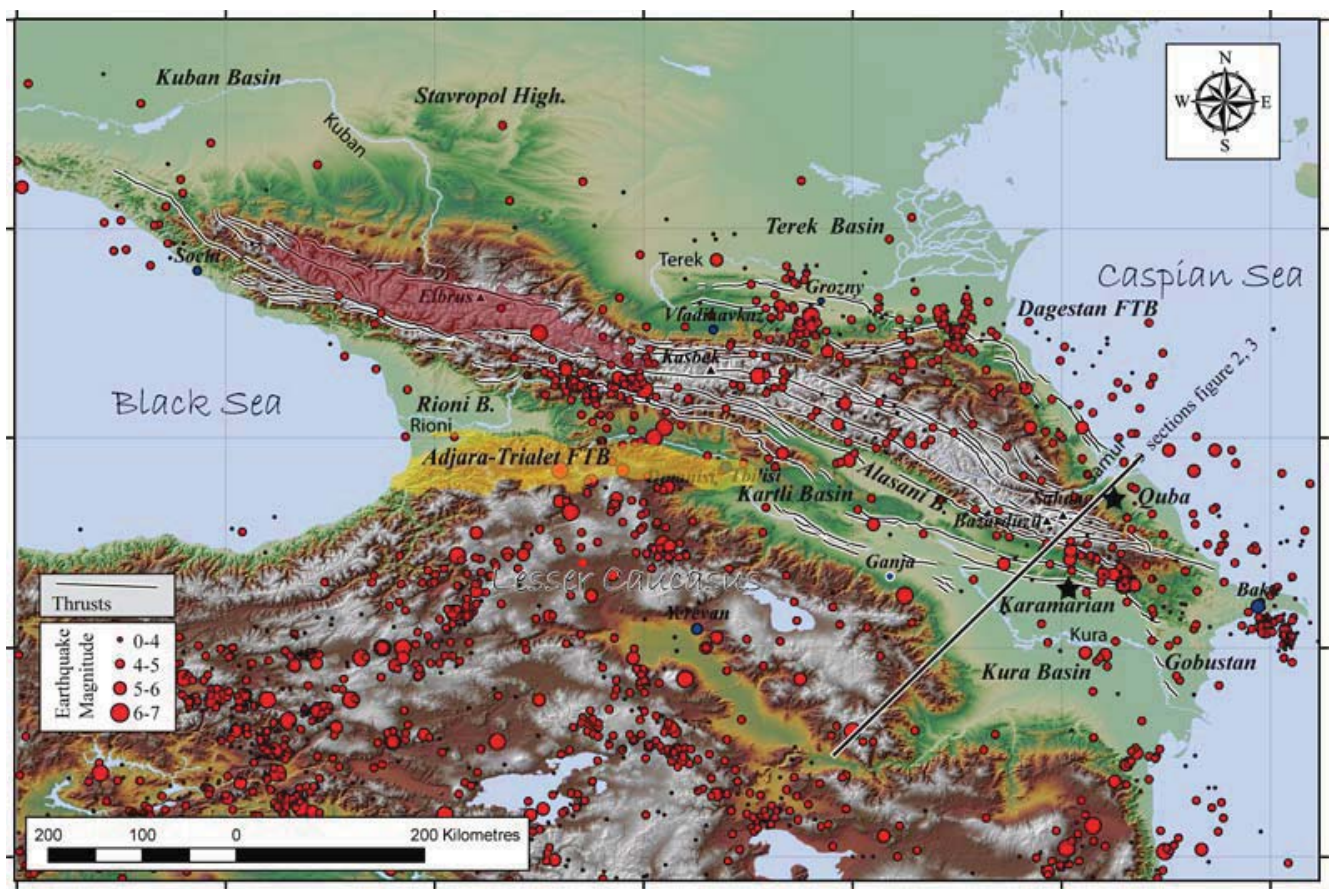

Fig. 1. General map of the larger Caucasus area with topography and earthquake distribution. Not all existing thrusts are shown only a selection of the major thrusts of the Greater Caucasus relevant for the discussion. Transparent red indicates the pre-Mesozoic core. Yellow highlighted area is the Adjara-Trialet fold-and-thrust-belt. Black triangles are mountain summits of the Greater Caucasus, black stars correspond to localities cited in text.

component of convergence and a complex plate boundary with vertical and horizontal strain partitioning (Jackson 1992). Recent convergence rates of up to $14 \mathrm{~mm} \mathrm{a}^{-1}$, strong earthquakes, landslides, active volcanoes, and extreme subsidence and surface uplift rates are indicative for the dynamics of the continent-continent collision. From east to west, the morphological shape and the structural features are strongly influenced by the rotational convergence of the Arabian plate and westward escape of the Anatolian Plate causing distinct tectonic regimes in the Caucasus. The Lesser Caucasus area is dominated at present by a strike-slip regime, whereas the Greater Caucasus is dominated by thrust tectonics with a main NNE-SSW direction of movement. The dominant movement is top to the south in the main range and the southern slopes. Top-to-the-north motion is observed in the areas in the north and in Dagestan.

Hereafter we will present different aspects of Cenozoic and recent tectonics, and tectonic geomorphology, especially based on detailed structural studies carried out over several years in the eastern Greater Caucasus in Azerbaijan. We shall discuss their relevance for understanding the thrust kinematics and the links between tectonics, topography, seismicity and uplift in the Greater Caucasus.

\section{Regional tectonics and geodynamics}

The geodynamics of the Greater Caucasus orogen correspond to an intercontinental collision zone inverting a deep Mesozoic-Cenozoic basin (Fig. 2) that is not located above a subduction regime, but bordered east and west by super deep sedimentary basins that have their origin in the Mesozoic and are filled with Cenozoic-Quaternary sediments. To the north and south of the Greater Caucasus are the foreland basins of the Terek-Kuban and the Kura-Kakheti-Kartli-Rioni, respectively (Ershov et al. 1999; Mikhailov et al. 1999; Ulminshek 2001; Daukeev et al. 2002; Ershov et al. 2003); to the east and west are the Caspian Sea and the Black Sea, respectively (Shikalibeily \& Grigoriants 1980; Berberian 1983; Ismail-Zade et al. 1987; Narimanov 1992; Abrams \& Narimanov 1997; Mangino \& Priestley 1998; Nikishin et al. 1998; Allen et al. 2002; Brunet et al. 2003; Nikishin et al. 2003). The Lesser Caucasus is situated above an old, possibly detached subduction slab (Hafkenscheid et al. 2006). An incipient subduction 


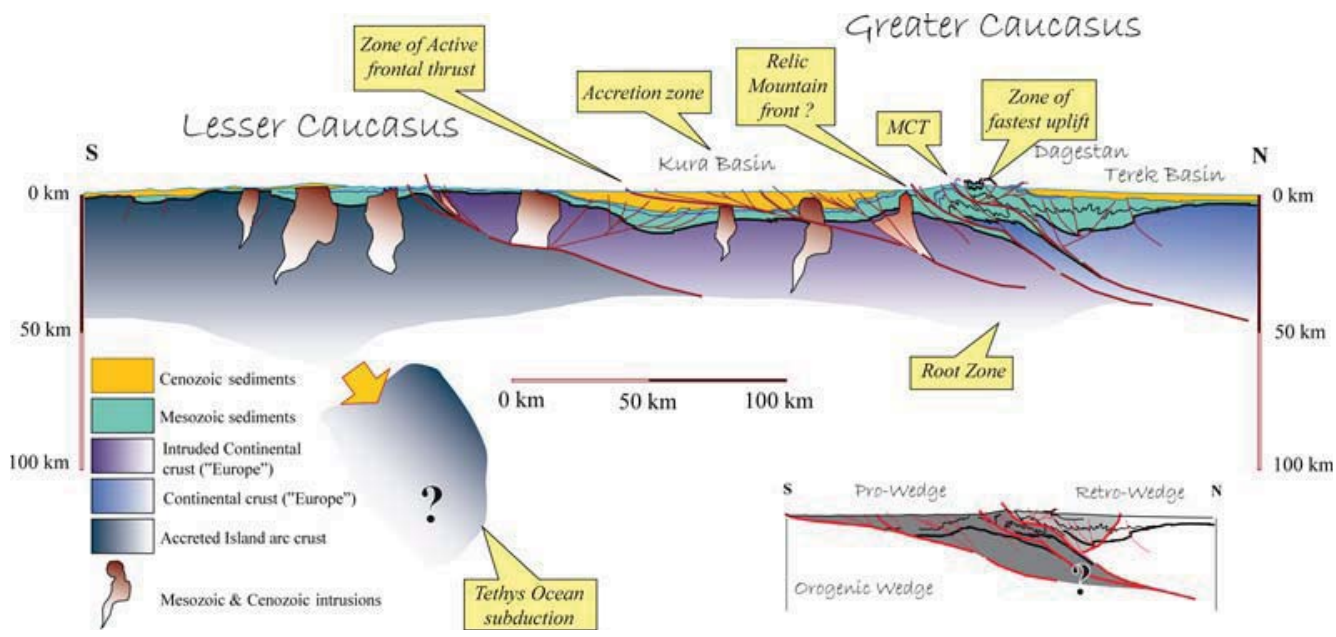

Fig. 2. General crustal-scale cross-section through the eastern Greater Caucasus and the Lesser Caucasus (location see Fig. 1). The Lesser Caucasus is associated with a northward subduction and possibly a detached slab [based on tomography after Hafkenscheid et al. (2006)]. No subduction is seen under the Greater Caucasus. The Greater Caucasus is a doubly verging orogenic wedge with the dominant thrusting towards the pro-wedge to the South. A retro-foreland fold-and-thrust belt develops to the north in Dagestan (Russia) see also Figure 1. Three different types of crust have been distinguished according to their geodynamic belonging: to the South a crust intruded and associated with the JurassicCretaceous suprasubduction arc volcanism in the Lesser Caucasus, in the centre the thinned and rifted and intruded southern part of the supra-subduction backarc basin, and to the north the northern part of this extended backarc rift system with the important Mesozoic sedimentary series of the Greater Caucasus Basin. Some major faults such as the Main Caucasus Thrust (MCT) are highlighted. The structure and the position of the thrusts at depth remains speculative, but indicate underthrusting of the terranes to the south of the Greater Caucasus and strong imbrication over a ramp system in the Greater Caucasus.

is believed to have occurred at the northern edges of the Black Sea, whereas in the east the subduction process was already initiated in Pliocene times, when the South Caspian Basin started subducting to the north under the eastern termination of the GC and the Apsheron Ridge (Allen et al. 2002; Knapp et al. 2004). The detailed link of the incipient subduction to the structures such as the Main Caucasus Thrust (MCT) in the Greater Caucasus remains to be investigated. The depth of the Moho changes from about $40 \mathrm{~km}$ beneath the Kura basin to more than $50 \mathrm{~km}$ beneath the eastern Greater Caucasus and rises to $40 \mathrm{~km}$ again under the northern foreland basin (Brunet et al. 2003; Ershov et al. 2003).

The Greater Caucasus is a doubly verging mountain-belt (Fig. 2) with two external fold-andthrust belts (FTB) and a complex nascent axial zone (Sholpo 1993; Khain 1997). The main tectonic underthrusting appears to be towards the north similarly as the subduction sense in the Lesser Caucasus - creating an overall asymmetry of the mountain range. The southward propagating meridional foreland FTB together with a large part of the axial zone form the pro-wedge (front) of the orogen (Khain 1975; Adamia et al. 1977, 1981;
Gamkrelidze 1986; Philip et al. 1989; Gamkrelidze 1997; Gamkrelidze \& Shengelia 2005). The KuraKartli and also the Rioni foreland basins are dissected by, and incorporated into, the outward propagating foreland FTB to the south of the main range. Deep seated southward migration of the orogenic front led to the inversion of the Pliocene to Late Pleistocene sediments, and the transport of the Alasani basin (Figs 1 \& 3a) as a piggy back basin towards the south.

Unlike in the western Greater Caucasus, a broad north-directed foreland FTB develops in the NE, in Dagestan and is part of the retro-wedge of the orogen (Kopp \& Shcherba 1985; Dotduyev 1986; Zonenshain et al. 1990; Sobornov 1994, 1996; Djavadova \& Mamula 1999). The Terek basin since the early Pliocene has subsided more than $4000 \mathrm{~m}$, and recently has exhibited pitted gravels of Early Pliocene age at $1600 \mathrm{~m}$ elevation. This northern FTB, similarly to the southern FTB, propagates into the Cenozoic-Quaternary series of the Terek Basin in the Dagestan area (Fig. 2).

Whereas the axial zone of the Greater Caucasus comprises Jurassic sedimentary rocks (Azerbaijan), a pre-Mesozoic basement (Georgia, Russia), and Pliocene intrusions, both external fold-and-thrust 


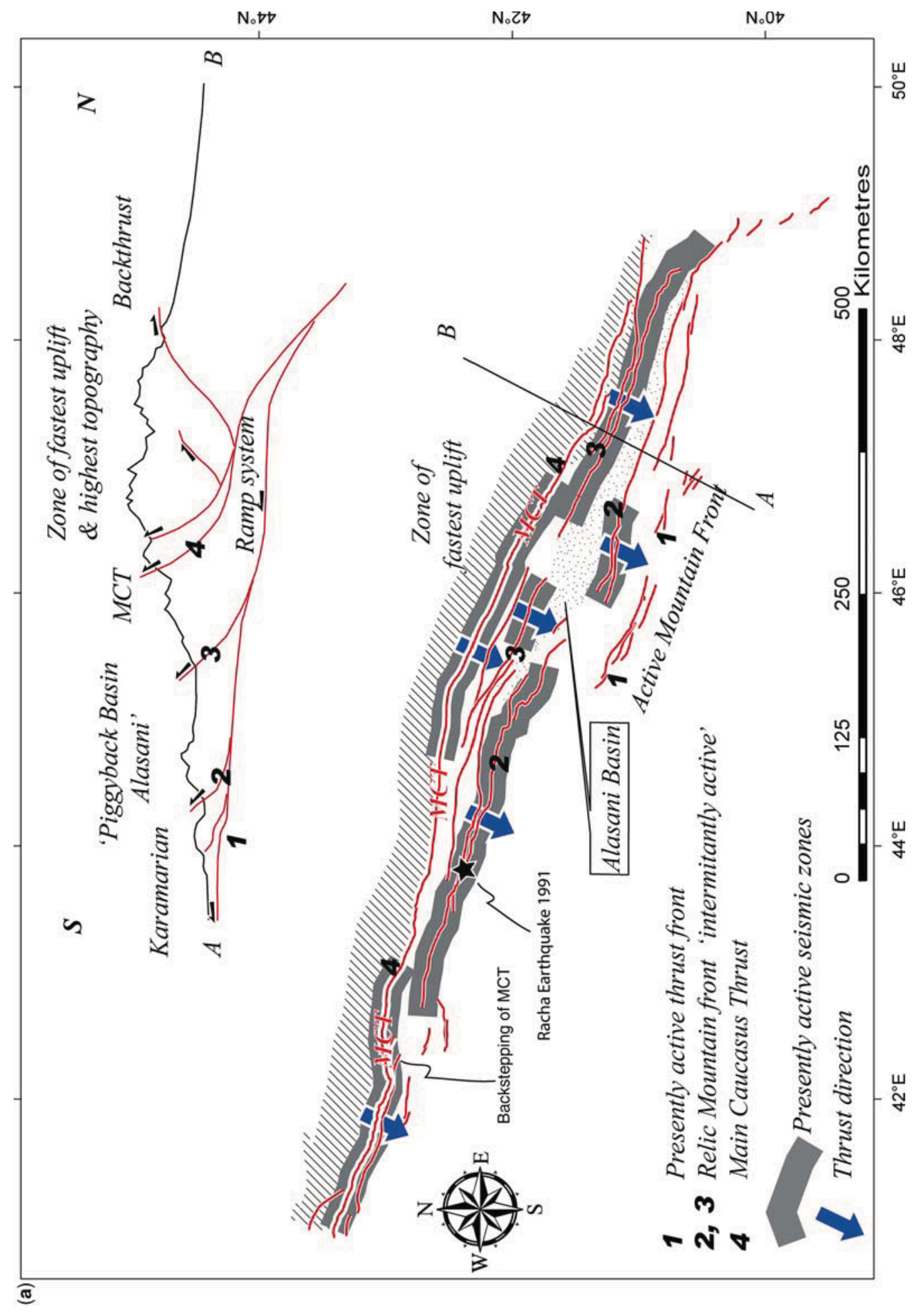




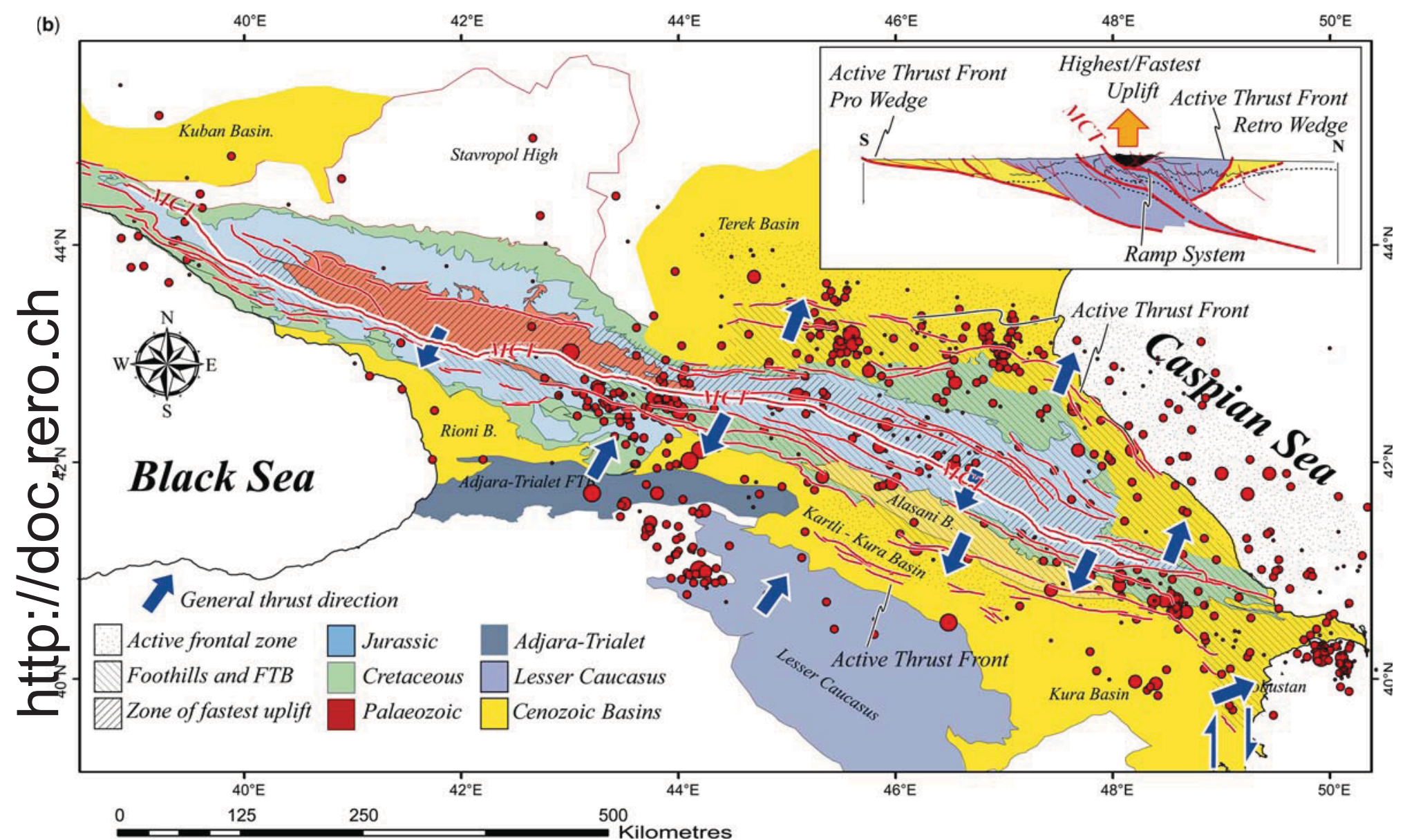

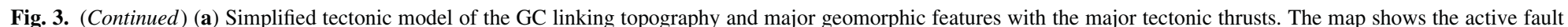

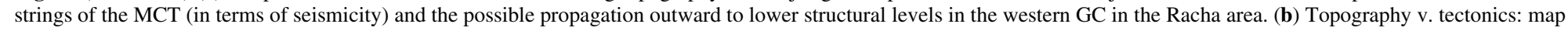

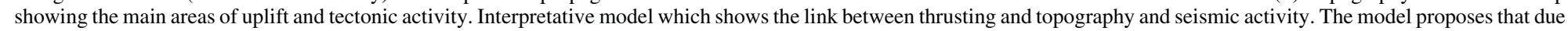
to motion over a ramp system at depth one can achieve fast uplift in narrow zone bound to forward thrust and back-thrust generated over the tectonic ramp. 
belts consist mainly of Cretaceous and Cenozoic sedimentary rocks (Khain 1997). The Greater Caucasus basin has developed in a back-arc setting to the southerly subduction-related volcanic arc of the Lesser Caucasus. Intrusive rocks are frequently found up into the Early Cenozoic, but mainly affect the southern parts of the basin (Sosson et al. 2010). Volcanoclastic series derived from the Lesser Caucasus volcanic arc are now found imbricated and folded in the southern foothills of the Greater Caucasus where they form distinct tectonosedimentary units (Kangarli 1982, 2005). In situ intrusives remain however rare and are associated with igneous activity on the margins to the south of the Greater Caucasus Basin (Mengel et al. 1987; Mustafayev 2001; Chalot-Prat et al. 2007).

Pliocene to Quaternary igneous activity is observed in the central part of the mountain range, in the border areas between Georgia and Russia (Tchechenia). The most outstanding examples are Mount Elbrus with $5642 \mathrm{~m}$ a.s.l. and further East Mount Kazbek (5047 m a.s.1.). These intrusions are mainly late-collisional, subalkaline granitoids that roughly range between 4.5 and $1.5 \mathrm{Ma}$ (Hess et al. 1993; Gazis et al. 1995; Nosova et al. 2005;
Lebedev \& Bubnov 2006), and culminate with Quaternary volcanism reaching into the Holocene (Lebedev 2005; Chernyshev et al. 2006).

Several successive tectonic events are documented in the Greater Caucasus sedimentary record. Precambrian and Palaeozoic (pre-Hercynian and Hercynian) tectonic phases are recorded in the preAlpine basement or Palaeozoic core (for discussion and references see Gamkrelidze \& Shengelia 2005; Kazmin 2006; Saintot et al. 2006a, b; Somin et al. 2006) and are followed by palaeotectonic events related to the Tethyan oceans (Palaeo- and Neotethys) (Nikishin et al. 1997; Barrier et al. 2008). These palaeotectonic events included extensional structures recorded throughout the Mesozoic cover of the Greater Caucasus Basin (Dotduyev 1986), but also unconformities thought to result from compressive phases such as the 'Eo-Cimmerian' (Triassic) and the 'Mid-Cimmerian' (CallovianBajocian) which is well documented in northern Azerbaijan (Fig. 4). The link of the latter unconformity to possible orogenic events remains speculative and debated.

The geometry of the Greater Caucasus sedimentary basin is of passive margin type with numerous

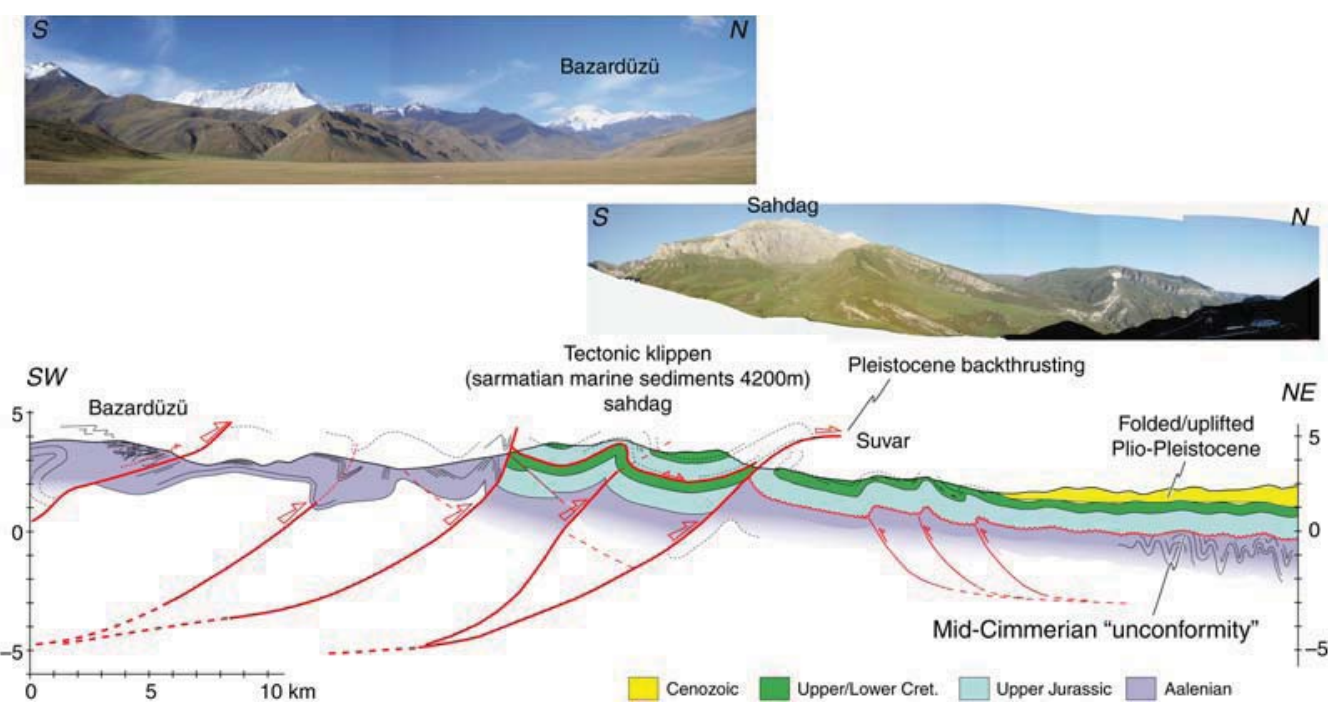

Fig. 4. Cross-section through the Sahdag mountain in north-eastern Azerbaijan. The section highlights the structural style at the northern edge of the mountain range. Thrusting is mainly to the north and of Plio-Pleistocene age. The Sahdag is built by a tectonic klippe that duplicates the Jurassic-Cretaceous series. The tectonic contact between the klippe and the underlying series is possibly a synsedimentary fault associated with the collapse of the carbonate platform during Cretaceous. To the north the Oxfordian overlies discordantly older folded series of the Middle to Lower Jurassic. This unconformity reflects the Mid-Cimmerian event. On the summit of the Sahdag Sarmatian rocks of marine origin document a vertical uplift of some $3700-4000 \mathrm{~m}$. Plio-Pleistocene detrital series including conglomerates are uplifted and folded (seen further east along strike the same structure). Photos: (a) View towards the west on the Sahdag Klippe which is on of the zones of fastest uplift in the whole area. Rocks range from Cretaceous to Jurassic in age. (b) View to the SW from Sahgdüzü (2500 m a.s.1.) to Bazardüzü range which is the highest range in Azerbaijan culminating at more than $4000 \mathrm{~m}$ a.s.l. Rocks are mainly of Lower Jurassic (Aalenian) age. 
tilted blocks. The central part of the orogen - where the oldest series outcrop, and topography is the highest - represents a distal basin between a platform domain to the north and a distant deeper domain with a structural high (tilted block) to the south. The foreland basins associated with the orogenic evolution are filled with Cenozoic and Quaternary sediments. In the south they build on top of the former distal, stretched continental margin (Greater Caucasus Basin), in the north they build on a flexural foreland underlain by a carbonate platform (Ershov et al. 1999). During the growth of the orogen since the Early Cenozoic the thrust front is propagating out into its own foreland basins. Especially the southern basins develop into a succession of piggyback foreland basins, subsequently and progressively abandoned (relic thrust fronts) as the orogenic front migrates southward. A typical example of an abandoned basin is the Cenozoic-Quaternary Alasani Basin (Philip et al. 1989) (Figs 1 \& 3a).

Distinct tectonic zones, from north to south, are separated by major thrusts (Dotduyev 1986). They correspond to the original palaeogeographic setup and build upon inherited, pre-existing structures (Egan et al. 2009). Lateral correlations and differences can be made between the western region in Crimea (Saintot et al. 1998; Saintot \& Angelier 2000; Saintot et al. 2006a), through Georgia (Gamkrelidze \& Rubinstein 1974; Gamkrelidze \& Gamkrelidze 1977; Banks et al. 1997) to the Caspian Sea (Kangarli 1982, 2005; Allen et al. 2003; Egan et al. 2009). The Adjara-Trialet FTB in Georgia located to the south of the southern limit of the Greater Caucasus in Georgia (Banks et al. 1997; Gudjabidze 2003) is of particular interest since thrusting is top to the North, opposite the direction in the GC (Gamkrelidze \& Kuloshvili 1998).

One of the major structural features in the GC is the Main Caucasus Thrust (MCT) (Dotduyev 1986). This large thrust can be observed along strike of the mountain belt over a distance of more than $1000 \mathrm{~km}$ (Figs $5 \& 3$ ). Displacement on this major thrust fault is top to the South, possibly in excess of $30 \mathrm{~km}$ in some places. In the west in Russia and Georgia, the MCT separates the Palaeozoic metamorphic core of the mountain range from the Jurassic cover series to the South. Further east in Georgia, Dagestan (Russia) and Azerbaijan it is found in the core of the orogen, separating rocks of different Jurassic ages. The definition of the MCT used here is according to Dotduyev (1986). Some recent papers (Kadirov et al. 2008) mistakenly label the thrust separating the Alasani Basin from the terrains in higher topographic elevations to the north as MCT. This latter thrust is believed to be a relic thrust front of early Cenozoic age. In eastern Azerbaijan, east of Mount Bazardüzü (the highest summit in Azerbaijan, Fig. 1), we lose the trace of the MCT and fieldwork has shown that is relayed by a string of fault-related folds.

\section{Active tectonics, convergence and uplift}

\section{Earthquakes and active faults}

The Greater and Lesser Caucasus are seismically active zones linked to the rapid and non-uniform plate convergence between Arabia and Eurasia (Philip et al. 1989; Jackson 1992; Priestley et al. 1994; Triep et al. 1995; Jackson et al. 2002; Allen et al. 2004, 2006) (Fig. 1). The Lesser Caucasus and the adjoining Anatolian Plateau show a predominance of strike-slip focal mechanisms associated with a system of vertical faults. In the Greater Caucasus, on the contrary, convergence is accommodated predominantly by reverse focal mechanisms associated to thrusting with a general north-south to NE-SW compression (Koçyigit et al. 2001; Barazangi et al. 2006; Copley \& Jackson 2006; Tan \& Taymaz 2006), see also discussion in (Jackson 1992; Allen et al. 2004). Slip vectors based on earthquake focal mechanisms show a general top-to-the-south thrusting. Strike-slip mechanisms exist but are rare. Present seismicity is unevenly distributed across the GC (Figs 1 \& 3). A zone with a higher seismic activity is observed on the south slope of the Greater Caucasus west of Tbilisi (Georgia) in the Racha area (Triep et al. 1995). Studies of focal mechanisms and focal depths show that this seismicity is linked to several active fault strings in the subsurface of the Gagra-Dzhava zone (Triep et al. 1995; Gamkrelidze \& Kuloshvili 1998). They show south directed slip vectors. These faults are located to the south and are structurally in the footwall of the MCT. To the west this fault system links to the MCT precisely where this latter shows an important bend, and is stepping back (to the north) into the mountain range (Figs $1 \& 3 \mathrm{a}, \mathrm{b}$ ). We suggest that the MCT is developing a new splay, and that the higher seismicity in this region is due this propagation of the MCT to the SW and to a lower structural level (Fig. 3a). To the east this fault system may be correlated with the thrust fault at the front of the Alasani Basin. It is relevant to notice that elsewhere in the Greater Caucasus the largest earthquakes known (earthquakes $>$ magnitude 6 , both historical and measured) are all located in the vicinity of the MCT. We interpret this to show the importance of the MCT to the present day in the deformation processes, since large earthquakes occur along large faults accommodating important displacement. The MCT appears to be a major thrust in the development of the Greater Caucasus.

Seismicity is extending into the Middle and South Caspian Sea (Kovachev et al. 2006). In 
the Apsheron zone focal mechanisms show NNESSW oriented thrusting (Jackson et al. 2002) and seismic activity may be linked with an extension/termination of the Greater Caucasus towards the East and/or with young north-directed subduction of the South Caspian Basin to the North under the Apsheron (Allen et al. 2002; Knapp et al. 2004). The seismicity further south as well as in the Gobustan desert area shows a westward component of motion relative to Eurasia, suggesting underthrusting towards the west (Jackson et al. 2002).

Some seismic activity is also seen in the central part of the eastern Greater Caucasus, as well as in the Kura basin. On the northern slopes, the Dagestan FTB and the recent faults in the Terek Basin show a higher concentration of earthquakes pointing to active thrust tectonics in this area.

Studies on palaeoseismology remain rare but confirm the existence of inherited faults and the possible 2000 year recurrence of high magnitude events (Rogozin et al. 2002; Rogozin \& Ovsyuchenko 2005).

\section{Convergence and uplift}

Studies based on GPS technologies in the larger Caucasus area, including Turkey, Arabia and Iran have confirmed the global picture of convergence across the Caucasus (McClusky et al. 2000; Nilforoushan et al. 2003; Reilinger et al. 2006). The average convergence of Arabia and Eurasia of $18-23 \mathrm{~mm} \mathrm{a}^{-1}$ is transformed into a deformation of $14 \mathrm{~mm} \mathrm{a}^{-1}$ with a north-south direction across the Greater Caucasus, mainly the southern part (Vernant et al. 2004). Detailed studies in Azerbaijan (Kadirov et al. 2008) confirm a rotational convergence between Arabian and European plates. Shortening is distributed between the Northern Kura Basin and the outermost thrusts of the Dagestan FTB. Present-day slip rates decrease from $10 \pm 1 \mathrm{~mm} \mathrm{a}^{-1}$ in eastern Azerbaijan to $4 \pm 1 \mathrm{~mm} \mathrm{a}^{-1}$ in western Azerbaijan (Kadirov et al. 2008). A similar study in Georgia shows the opposite thrust directions between south-dipping thrusts in the Adjara-Trialet FTB and the Greater Caucasus front, which shows relative motion of $6.9 \pm 1.1 \mathrm{~mm} \mathrm{a}^{-1}$ to the SW on north-dipping thrusts (Gamkrelidze \& Kuloshvili 1998). These studies also show a marked change (decrease) in velocities across the MCT. Indeed north of the MCT velocities are almost 0 , indicating no longitudinal displacement. All deformation appears to be taken up in uplift.

Across the more or less north-south oriented West Caspian Fault - at the transition Kura basin to Gobustan area near the eastern shores of the South Caspian Sea - a recent study indicates a dextral strike-slip motion and calculates a differential movement of $11 \pm 1 \mathrm{~mm} \mathrm{a}^{-1}$ (Kadirov et al. 2008).

\section{Uplift/subsidence and tectonics v. topography}

\section{Subsidence studies}

The Greater Caucasus basin was initiated by Mesozoic back-arc extension related to the subduction of the Tethys Ocean to the south (Brunet et al. 2003; Barrier et al. 2008). A large part of the subsidence occurred during this rift-related crustal extension, prior to the subsequent Cenozoic mountain building and the subsidence observed both north and south of the Greater Caucasus.

Rapid subsidence occurred there in a foreland basin setting, in different phases during the Cenozoic. The North Caucasus foredeep (Kuban and Terek basins mainly) can be described in three major periods: Early Jurassic to Late Cretaceous related to initial rifting then cooling followed by a Late Cretaceous to Middle Eocene phase of alternating subsidence and uplift as a far field effect of the suturing of the Tethys Ocean to the south (Mikhailov et al. 1999). The period of Late Eocene to present relates to the development of a foreland basin coeval with shortening and uplift in the adjacent Greater Caucasus range. In the Black Sea and South Caspian basins (Brunet et al. 2003), the much more rapid Pliocene-Quaternary phase of sedimentary infill as well as subduction related subsidence in the north of South Caspian (Egan et al. 2009) occurred simultaneously with the asymmetrical subsidence of Caucasus-related molasse basins to the north and south (Ershov et al. 1999, 2003). A crustal/lithospheric - scale model suggests that crustal thickening and removal of lithospheric roots are responsible for supporting the Caucasus Mountains. Subsidence is explained by loading of the lithospheric roots (Ershov et al. 1999). The Eocene-Early Oligocene phase of subsidence is associated with cessation of subduction in the southern areas of the Lesser Caucasus, while the rapid Middle Miocene to Present subsidence is linked to the final closure and inversion of the Greater Caucasus Basin.

\section{Uplift-exhumation}

The Caucasus offers numerous geomorphic field lab conditions to apply classic methods such as terrace deposits studies or 'young' marine sediment age/ altitude studies, palaeogeography and palaeoclimate/environment, and more modern ones such as fission track studies on apatite or zircon. 
(a)
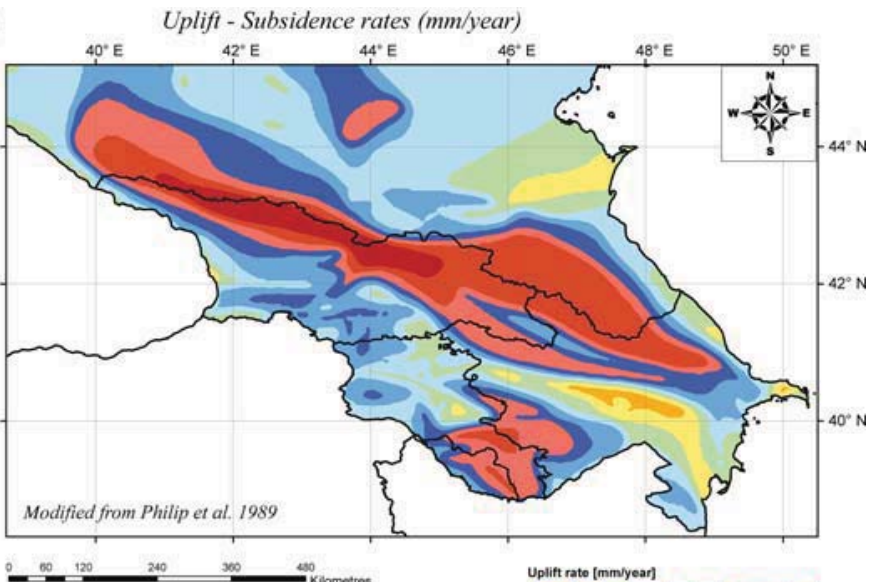

Upilit rato [mm/year]

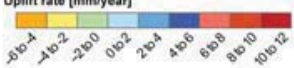

(b)

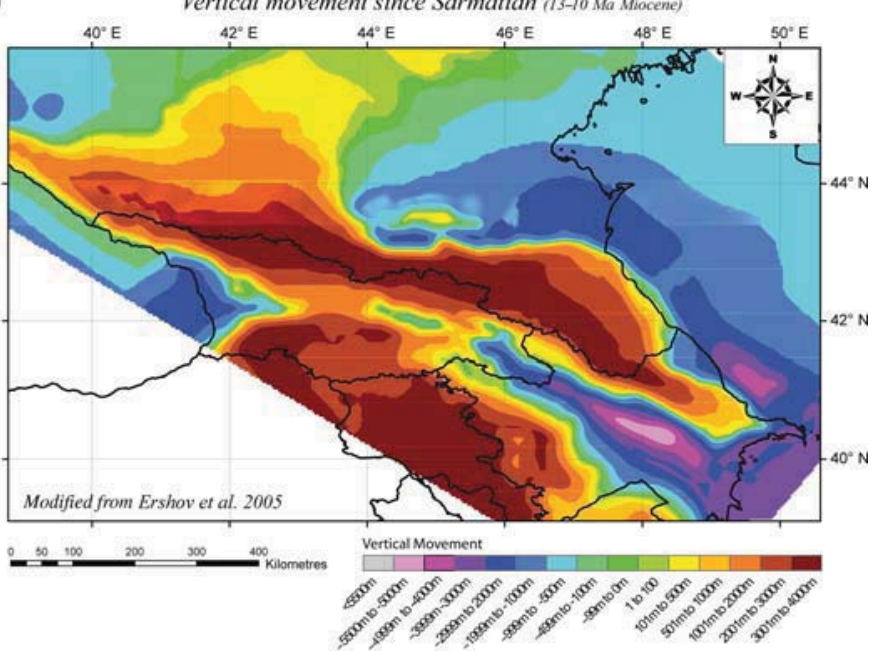

(c) Lower Pleistocene-Coastline v. Palaeotopography

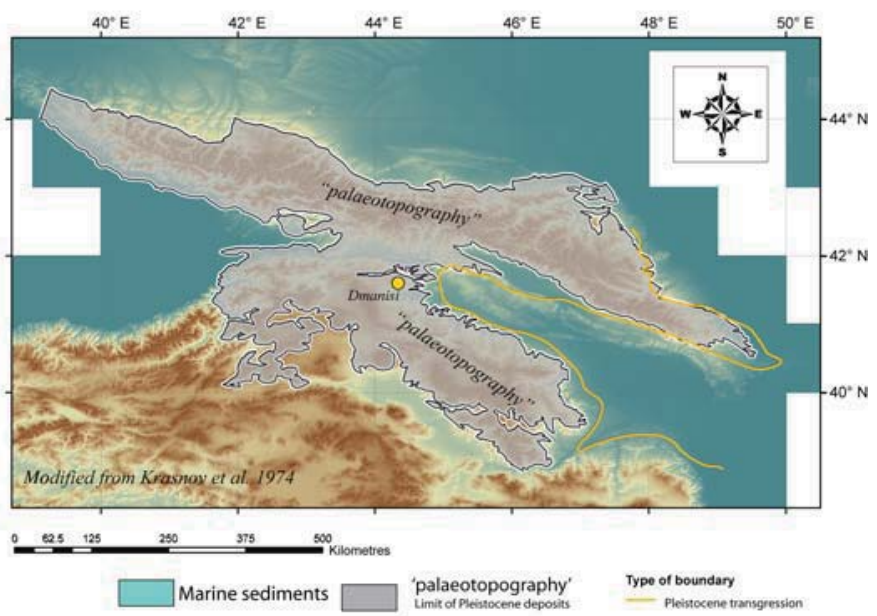

Fig. 6. 
Geomorphologic research (Mitchell \& Westaway 1999) and minor thermochronological investigations show a very young heterogeneous rock and surface uplift in the Greater Caucasus. A study on pre-alpine basement rocks shows ages based on apatite fission track studies younger than $68 \mathrm{Ma}$ in agreement with the general idea of an uplift that initiated in the Cenozoic (Kral \& Gurbanov 1996). Patterns of age distributions also indicate uplift of 7-4 Ma in some areas, suggesting a strong influence of recent tectonics in the process of exhumation/ uplift. Studies on cooling history of recent granites in the western central Greater Caucasus show ages between 2.5 and 1.2 Ma and suggest uplift rates of $4 \mathrm{~mm} \mathrm{a}^{-1}$ (Hess et al. 1993), but thermal modelling difficulties linked to the close vicinity of hot intrusives may significantly modify modelling results leading to overestimates of the uplift rates.

Compilation of uplift amount and uplift rates (Philip et al. 1989; Ershov et al. 2005), confirm the very young uplift (Fig. 6a, b) but show uplift rates in excess of $12 \mathrm{~mm} \mathrm{a}^{-1}$, which in light of field evidence (see Mitchell \& Westaway 1999 for discussion) seem very fast. However, they consistently show that the fastest and highest uplift is in the centre of the range. A more recent study on apatite fission tracks on the Early Miocene Maikop series of the western Greater Caucasus shows the detrital provenance of the clasts and suggests a minimum Early Oligocene age for subaerial uplift of the mountain range (Vincent et al. 2007). Work in progress by our group on apatite fission track data in Azerbaijan, showed similar inherited ages of 12-56 Ma for samples taken in conglomerates of Pliocene age north of Mount Sahdag (Fig. 4). Ages of $21.8 \mathrm{Ma}$ from samples taken in Aalenian sandstone in the central part of the range south of Mount Sahdag (Fig. 4) confirm the Cenozoic uplift.

Detailed studies on geomorphology, including the young terraces along the Black Sea and Caspian Sea (Brod 1962; Krasnov et al. 1974), or the Kura Basin (Shirinov 1973; 1975) exist but are all in Russian and difficult to access (Budagov 1969, 1973; Shcherbakova 1973; Shirinov 1975). One of the most prominent geomorphologic archives directly relating to uplift are the marine and river terraces. Up to 14 levels of terraces are recognized and reach into the valleys of the Greater Caucasus. A terrace at $475 \mathrm{~m}$ a.s.l. is given as latest Pliocene in age (Fig. 6c), and is found along the western shore of the Caspian Sea (in Azerbaijan) and in the Kura basin along the foothill of the Greater and Lesser Caucasus. It reflects the location of the Pleistocene marine coastline corresponding to the Late Akchagyl transgression of the Caspian Sea (Krasnov et al. 1974; Popov et al. 2004). Its age is given as between 2.5 and $1.8 \mathrm{Ma}$ possibly as young as $1.2 \mathrm{Ma}$ (see Mitchell \& Westaway 1999 for discussion and references). This is the same period that the oldest hominids in the Caucasus area were living in the Dmanisi (Georgia) area, near the ocean shores of the eastern Paratethys (Lordkipanidze et al. 2007). Many other terraces can be seen up to altitudes of $3000 \mathrm{~m}$ into the mountain valleys; their potential to help date uplift or show intramontane erosional/depositional processes remains to be investigated. Evidence from river incision of several hundred of metres since the last glaciations suggests uplift rates of $10 \mathrm{~mm} \mathrm{a}^{-1}$ (Rastvorova \& Shcherbakova 1967). Similar deep incisions are also observed in Plio-Pleistocene sediment of the Samur river in northern Azerbaijan, however detailed studies need to confirm the fast uplift rates.

The development of palaeo-rivers such as the Kura (Djavadova \& Mamula 1999), Volga, Terek and Samur rivers, and provenance studies have been given great attention in recent years due to oil exploration studies (Reynolds et al. 1998; Guliyev et al. 2003; Morton et al. 2003). They transport the sediments from their source area to their final sinks. All this development, younger than $10 \mathrm{Ma}$, possibly even $5 \mathrm{Ma}$, led to the formation of very high quality reservoirs making the circum Caucasus basins unique oil provinces. The river systems and their deltas also underline the rapid lateral changes between areas with high and low topography or below and above sea-level. The longlived river systems have also left a complex system of terraces, both in the valleys cutting into the mountain belt (mainly parallel and perpendicular to the main structural trend, (Lukina 1981)). The existence of several levels and ages of river terraces document continued incision possibly due to uplift of the mountain range (Shirinov 1973). This is also shown by the important cliffs of Quaternary material cannibalized on the northern slopes of the eastern Greater Caucasus near Quba (Figs 1 \& 4) (Kangarli 1982). Connecting these 'events' to the different levels and ages of terraces along the

Fig. 6. (Continued) Maps of uplift rates, vertical movement, and Lower Pleistocene coastlines. (a) Uplift rates: map shows that highest rates of $10-12 \mathrm{~mm} \mathrm{a}^{-1}$ are found in the central part of the western Greater Caucasus (Philip et al. 1989). High subsidence is occurring in the Kura Basin. (b) Total vertical movement since Sarmatian (10-13 Ma Miocene). Strong subsidence is seen north and south of the eastern termination of the Greater Caucasus in Azerbaijan (Ershov et al. 2005). (c) Lower Pleistocene coastline - map of coastline (Krasnov et al. 1974) which separates the area of the former marine domain and zone above sea-level with Pleistocene deposits, and area with unknown amount of palaeotopography. Notice the position of Dmanisi (Georgia) where hominid remnants dated back to 1.8 Ma have been discovered. 
Caspian Sea (Shcherbakova 1973; Mamedov 1997) opens the prospect of quantifying uplift v. subsidence and basin infill.

One of the best data sets to directly quantify uplift are marine sediments such as those of Sarmatian age now found at altitudes of $3700-4000 \mathrm{~m}$ a.s.l. such as in the Sahdag area of Azerbaijan (Budagov 1963) (Fig. 4). Akchagylian marine clays are found in the Budur (localiser) syncline at altitudes of $2000 \mathrm{~m}$ a.s.l. in the Azerbaijan Greater Caucasus (Kangarli 1982). Combined information from different datasets suggest uplift rates between 0.33 and $1.00 \mathrm{~mm} \mathrm{a}^{-1}$ for the last $10 \mathrm{Ma}$ in eastern Greater Caucasus (Mitchell \& Westaway 1999) but detailed rates for the different periods remain uncertain.

\section{Palaeogeography}

During the Cenozoic the Greater Caucasus formed a vast island within the landlocked Paratethys Sea. Detailed palaeogeographic reconstructions indicate that the Greater Caucasus is emerging above sea level as lowland only after the mid Middle Miocene (13-14 Ma) to grow into a mountain range after Late Miocene (11-10 Ma) to MiddleLate Pliocene 3.4-1.8 Ma) (Popov et al. 2004). Palaeoclimate studies using spores and mostly pollen from Sarmatian (12-8 Ma), mostly marine sediments, in Georgia north of Tbilisi show the existence of pine forest at moderate to high altitudes and reflecting important climatic changes linked to mountainous topography and orogenic evolution (Shatilova 1992; Shatilova et al. 2008; Kokolashvili \& Shatilova 2009). Prior to this Mid Miocene period, palaeogeographic reconstructions only indicate lowlands or islands or locally in the western Caucasus area mountainous areas. This is at odds with the fact that tectonic convergence and thrusting started already in Late Eocene times and most likely generated considerable topography. This is corroborated by the fact that important quantities of sediments are deposited in peripheral basins starting in Eocene-Oligocene, and that are most likely sourced in the nascent Greater Caucasus. An early Oligocene uplift is also confirmed by provenance studies and fission track investigations in the Maikop series (Early Miocene) of the western Greater Caucasus (Vincent et al. 2007).

\section{Tectonic geomorphology}

Only a few combined studies on tectonics and geomorphology (Burbank \& Anderson 2001; Keller \& Pinter 2002; Delcaillau 2004) are available in the Greater Caucasus such as an investigation of the Alasani basin on the southern slope of the Greater Caucasus in Georgia (Philip et al. 1989; Triep et al. 1995).
This latter basin, runs parallel to the southern slope of the Greater Caucasus (Figs 1 \& 5) and is filled with Pliocene-Quaternary sediments. This basin is bound to the north by one or several thrusts separating it from the steeper slopes rising into the high mountain range (Philip et al. 1989). To the east in Azerbaijan it can be shown that these faults are thrusting Cretaceous rocks over Oligocene series in the Basqual area (north of the town of Agsu; Fig. 7) (Kangarli 1982). Its front to the south is bound by a thrust-related fold which leads to a sharp topographic drop down to the Kura plain. The Alasani basin is thus an intramontane, piggyback-type basin with a relic thrust front that was active in the Miocene along its northern edge and a frontal thrust which is active in PlioceneQuaternary just south of the basin. In Georgia the Gagra-Dzhava zone located in the southern foothills of the main range is playing a similar role (Gamkrelidze \& Gamkrelidze 1977; Dotduyev 1986; Gamkrelidze 1991). Its structure is similar to the Alasani Basin, but in addition shows somewhat farther travelled outliers of the main range, as is the case in the Basqual nappe structure in Azerbaijan (the eastern equivalent of the Alasani basin).

Further to the south the Quaternary sediments of the northern part of the Kura-Kartli basin are folded and thrusted. Very prominent in the morphology the Karamarian Quaternary Anticline in Azerbaijan (Girdimanchai River - city of Agsu; (Figs 1 \& 7) is a large doubly plunging anticline showing well developed water gaps formed by tributaries of the river Girdimanchai (Fig. 7) (Shirinov 1975). A large asymmetric south-verging anticline is developed over a blind thrust with splays. The water gaps were cut during thrust-related folding and the fast changes in tectonics (leading to local uplift that was not matched by erosion) caused the change to wind gaps for some valleys. In western Azerbaijan the active thrust front extends all the way into the foothills of the Lesser Caucasus, folding alluvial fans and forming gentle topographic highs and tilted terraces.

Vertical faults with a strike-slip motion, are clearly reflected in the morphology as seen in examples from the Lesser Caucasus in Turkey and Georgia, as also discussed from earthquake focal mechanisms (Rebaï et al. 1993; Koçyigit et al. 2001). The importance of strike-slip tectonics in the Greater Caucasus has been suggested and discussed in many instances, however without conclusive or convincing evidence. Remote sensing studies of lineaments (rivers, and mountains crest, as well as faults (Cloetingh et al. 2007)) and field investigations on faults with strike-slip movements show a general pattern of NNE-SSW oriented young anti-Caucasian faults cross-cutting all the major fold-and-thrust structures. The general 

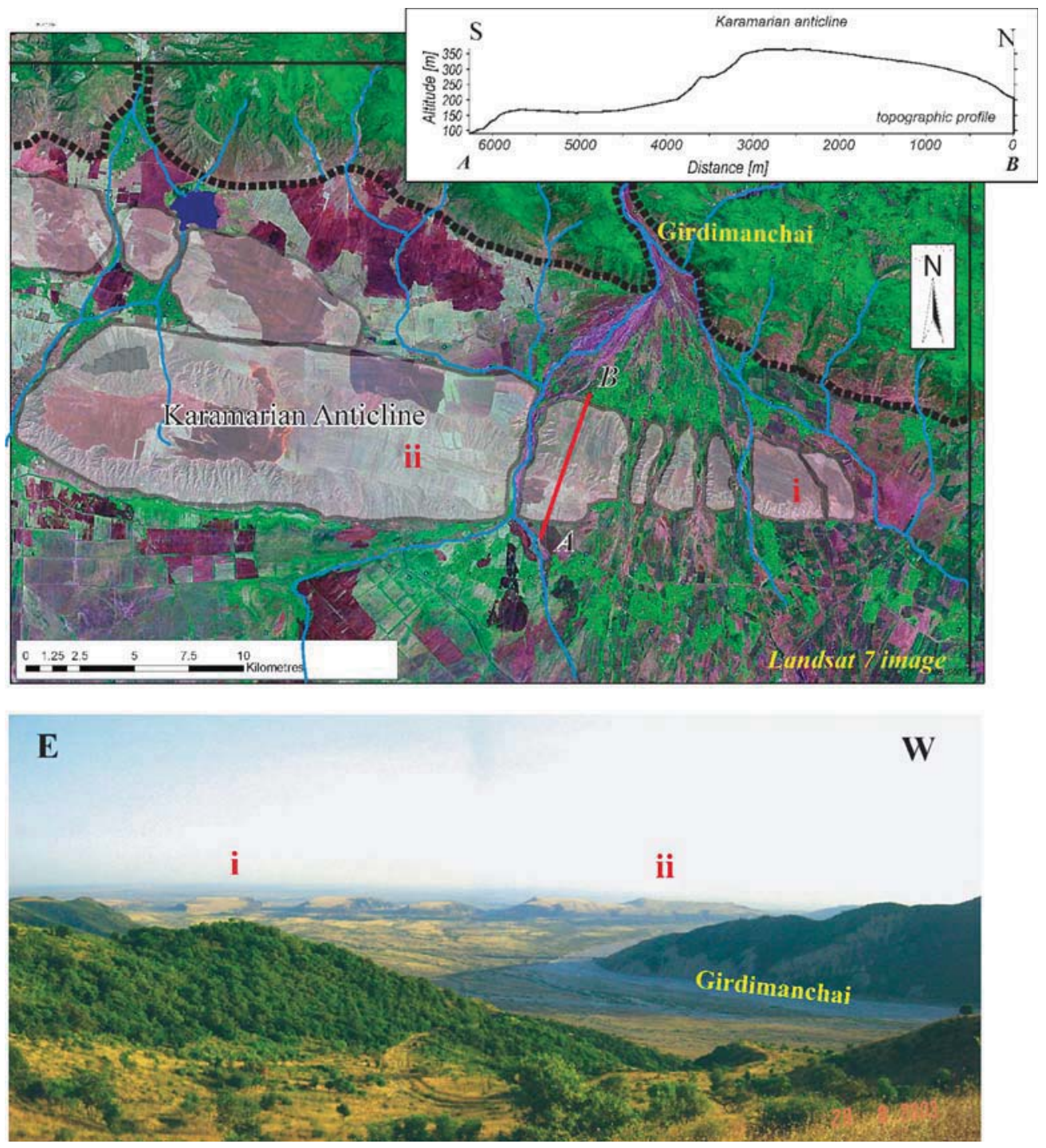

Fig. 7. Pictures of the geomorphology of the Karamarian anticline (top image; Landsat 7 image) in the northern Kura basin of Azerbaijan, near the city of Agsu. The doubly plunging anticline is cut by the river Girdimanchai to form water gaps due to river incision into the growing structure. Detailed topography along profile A-B (top right) shows the asymmetry of the Karamarian anticline, suggesting a buried thrust with top to the south movement. Dashed black line shows topographic limit of the southern steep slopes of the Basqual nappe unit (equivalent to the Alasani basin) to the north. Lower picture shows lateral view of the Karamarian anticline looking towards the south.

palaeostress orientation resulting from fault kinematic analyses shows a north-south to NNESSW oriented compression, with east-west extension and vertical intermediate stress axis confirming that they are recent faults that have suffered no rotation. However, no large-scale vertical faults or fault system crosscutting the whole mountain range could be observed.

\section{Topography and thrusts}

Based on a digital elevation model at $90 \mathrm{~m}$ we have extracted a contour map (Fig. 5) and superposed the main thrusts bounding the large changes in topography. Many thrusts coincide with changes in topography. In many other instances of topographic changes no thrusts are known, opening the 
possibility to denominate promising locations for thrusts, which remain to be ground-truthed. The most striking feature is the MCT which forms the southern limit of the zone of highest topography throughout the Greater Caucasus. The relationship topography - thrust trace is even more clearly shown on two topographic profiles through the eastern Greater Caucasus (Fig. 8). Especially the relic thrust fronts of the Alasani basin and the folds and thrusts of the Karamarian-Kakheti zone stand out from the flat surface of the Kura basin. The morphological changes associated with the present active thrust front at the foothills of the Lesser Caucasus are too small to show on the profiles. A second set of profiles showing the changes in slope emphasize the position of the main thrusts!

The combined use of topography and slope helps to determine the position of the major thrusts which can be refined by the use of more detailed geological maps and satellite imagery (work in progress on a new tectonic map of the Greater Caucasus). This method can be used as a prospective tool to determine active (in combination with seismicity), but also fossil thrusts or orogenic fronts.

The major topographic changes and thrusts can be followed throughout the whole Greater Caucasus.

\section{Discussion and conclusion}

New field evidence on thrust geometry, tectonic geomorphology, and tectonics combined with literature data on Cenozoic tectonics in Azerbaijan led us to investigate the relationship between tectonics, topography and uplift in the eastern Greater Caucasus and correlate and expand our findings along strike to the whole Greater Caucasus.

- The Greater Caucasus is an intracontinental doubly verging orogen resulting from the inversion of the Mesozoic, rift-related Greater Caucasus basin. The convergence between Arabia and Eurasia led to the closure of this basin and generated underthrusting and stacking of tectonic units. No subduction zone appears to exist under the Greater Caucasus, though incipient/young subductions are described for the western and eastern terminations of the Greater Caucasus into the Black Sea and Caspian Sea, respectively. During the orogenic development important foreland basins developed on both sides of the mountain range. Their development is contemporaneous with the infill of super deep sedimentary sinks in the Black Sea and the South Caspian Basin.

- The Greater Caucasus is a fast growing orogen that started to build to its present topography since Late Eocene. Detailed timing of uplift above sea level remains elusive, but there is clear evidence, including age and position of relic mountain fronts, that the orogen was growing in Oligocene and probably in Late Eocene already. The climax of growth was during the Late Cenozoic, starting in the Middle Miocene and accelerating in Plio-Pleistocene. Information about uplift remains very unevenly distributed. Total uplift since Sarmatian is in excess of $3700 \mathrm{~m}$ as documented in the Eastern Greater Caucasus in Azerbaijan. Uplift rates in excess of $10-12 \mathrm{~mm} \mathrm{a}^{-1}$ in the central part of the mountain range and based on river incision since the last glaciations, remain questionable and need to be confirmed especially when confronted with data showing more moderate uplift rates of 0.33 to $1.00 \mathrm{~mm} \mathrm{a}^{-1}$ over the last $10 \mathrm{Ma}$.

- The Main Caucasus Thrust is a discrete major thrust stretching across the whole Greater Caucasus from the shore of the Black Sea in the west to Azerbaijan in the east. In Azerbaijan and towards the shore of the Caspian Sea the MCT splits into several fault strings and affects a more diffuse zone, where both top-to-the-north and top-to-the-south thrusting is observed. The zone of highest topography, which correlates with the zone of fasted uplift, is bound to the south by the MCT which shows important top-to-the-south movement. To the north this zone is bound by south dipping thrusts with top-to-the-north movement. Detailed cross sections from northern Azerbaijan and insight from the Dagestan FTB suggest that this northverging backthrusting is linked to a thrust ramp system at depth. Thus the zone of highest uplift forms a triangular shaped domain limited to the south by the MCT and to the north by backthrusts. This triangular zone of fast uplift and its associated major topographic/tectonic features can be correlated across the whole Greater Caucasus. Uplift over such a more or less steep ramp system may also explain why we observe such important uplift (a minimum of $3700 \mathrm{~m}$ since Sarmatian) in a rather restricted area.

- Major displacement has been accommodated along the MCT as suggested from the location of the strongest earthquakes known is the area (>6 Mg). The 1991 earthquake of high magnitude in Georgia in the Racha area, but also by historical earthquakes in Azerbaijan such as in 1667 in the Shamakhi area occur on thrusts located to the south of the MCT. These quakes area in similar structural position on a thrust system structurally beneath and to the south of the MCT and we interpret them as outward (to the south) propagating splays of the MCT.

- Progressive southward migration of the thrust front during the Cenozoic formed successive active thrusts that were subsequently abandoned 
(a)

Topography Dagestan - Khaketi section
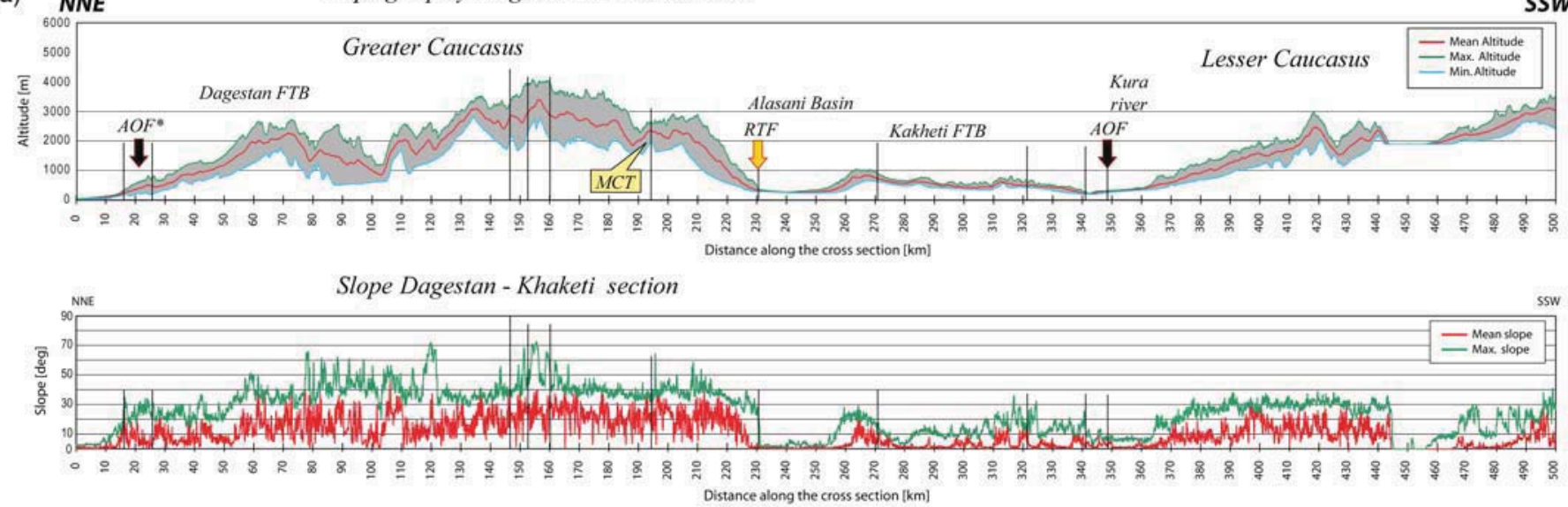

(b)

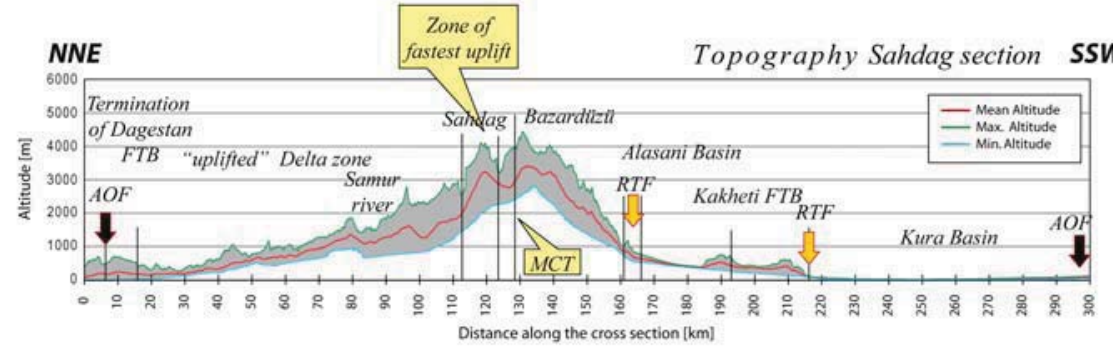

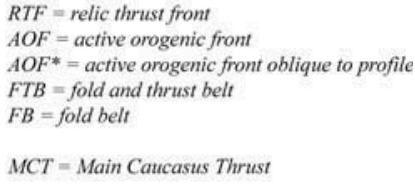

MCT $=$ Main Caucasus Thrust

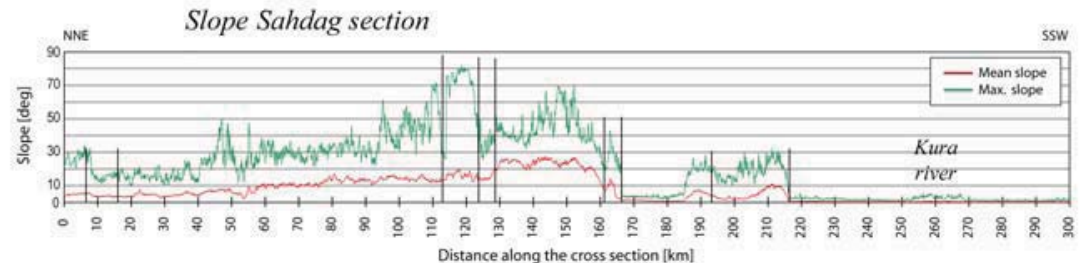

Fig. 8. Sections across the Greater Caucasus showing the average evolution of topography along two transects as well as the changes in slope along the same transects (position of cross-sections see Fig. 5). 
to form relic thrust fronts. The progression is registered in the geomorphology by clear changes in topography, deviation of rivers and water gaps. This is clearly documented in the thrust faults north, than south of the AlasaniBasqual (Basqual is a lateral structural equivalent of Alasani basin in Azerbaijan) structure, followed to the south by the Kartli FTP and the structures such as the Karamarian anticline. The active orogenic front zone, both to the north in Dagestan and to the south in the foothills of the Lesser Caucasus, can be deduced from morphological, structural and seismicity criteria.

- Unlike the western Greater Caucasus, the eastern Greater Caucasus is seismically very active. This high seismicity correlates with higher present convergence rates in this area. We suggest that this reflects the continued growth of the foreland basins outboard of the main range into the Quaternary to recent sediment filled foredeeps. Simultaneously, as suggested by earthquakes in the central parts of the orogen, we observe continued growth and uplift in the central part These zones correlate with the areas of high topographic gradients such as the MCT or other areas west of Tbilisi on the southern slope of the Georgian Greater Caucasus. The difference between east and west is due to different factors such as the east to west decreasing plate convergence rate. But, also the inherited structure possibly plays a major role. Indeed, the basement units present in the west are not observed to the east and this may be interpreted as a difference in the initial palaeotectonic setting that was subsequently differentially inverted during compression. In addition the observed recent magmatic activity in the west may suggest a difference in the crustal or whole lithosphere structure and strength contributing to a different evolution east and west.

- Strain partitioning across, and parallel to, the Greater Caucasus is very heterogeneous, both vertically and horizontally. Present day plate convergence as observed from GPS data is oblique with a larger convergence in the East. Overall this convergence converted into a $6-$ $14 \mathrm{~mm} \mathrm{a}^{-1}$ horizontal deformation across the Lesser Caucasus and the Greater Caucasus. An important drop in velocities across the MCT in the Greater Caucasus, indicates, in agreement with what we suggest in this paper, that there is no horizontal displacement, but dominantly uplift! The MCT is a main boundary north of which we observe the development of triangular zone of uplift related to an important tectonic ramp system at depth. West of Tbilisi (Georgia) in Racha area seismicity indicates partitioning of strain between the MCT and the thrusts beneath the Gagra-Dzhava zone. As seen from GPS data and tectonic geomorphology the meridional FTB and the thrust front is clearly propagating, but the present activity is the Dagestan FTB and foreland basin.

An example of vertical strain partitioning between surface and deeper structures is suggested at the eastern transition of the GC into the South Caspian basin. Here in the Gobustan area GPS data suggest a dextral strike-slip motion along a major fault, the West Caspian Fault, whereas earthquake focal mechanisms suggest a thrust motion to the east which may be linked with westward subduction connected with subduction of the South Caspian Basin.

Clear links between geomorphology, seismicity and tectonics can be observed in the Greater Caucasus. With the exception of the Racha area in Georgia, mainly the eastern Greater Caucasus appears to be active at present. Strain partitioning across the mountain belt is very heterogeneous. In the absence of enough detailed data precise timing and assessment of rates of uplift and deformation and the partitioning of strain into uplift and horizontal deformation, as well as the partitioning between thrusting and strike-slip remain difficult to assess.

We would like to thank especially the MEBE Programme and its sponsors for supporting this research. We are further indebted to the Swiss national science foundation for their financial support (SCOPES project IB7320110973) as well as INTAS (project 06-1000017-8930) and the University of Fribourg. We also would like to thank all the people in Azerbaijan and Georgia that were involved in this project and that helped in one way or another. We thank the reviewers for their constructive suggestions.

\section{References}

Abrams, M. A. \& Narimanov, A. A. 1997. Geochemical evaluation of hydrocarbons and their potential sources in the western South Caspian depression, Republic of Azerbaijan. Marine and Petroleum Geology, 14, $451-468$.

Adamia, S. A., Chkhouta, T., Kekelia, M., LordkipaNIDZE, M. B. \& ZaKariadZe, G. S. 1981. Tectonics of the Caucasus and adjoining areas: implications for the evolution of the Tethys ocean. Journal of Structural Geology, 3, 437-447.

Adamia, S. A., LordKipanidze, M. B. \& Zakariadze, G. S. 1977. Evolution of an active continental margin as exemplified by the alpine history of the Caucasus. Tectonophysics, 40, 183-199.

Allen, M., Jackson, J. \& Walker, R. 2004. Late Cenozoic reorganization of the Arabia-Eurasia collision and the comparison of short-term and long-term deformation rates. Tectonics, 23, TC2008, 1-16.

Allen, M. B., Jones, S., Ismail-Zadeh, A., Simmons, M. \& ANDERSON, L. 2002. Onset of subduction as the 
cause of rapid Pliocene-Quaternary subsidence in the South Caspian basin. Geological Society of America 30, 775-778.

Allen, M. B., Vincent, S. J., Alsop, G. I., IsmaIl-ZADEH, A. \& Flecker, R. 2003. Late Cenozoic deformation in the South Caspian region: effects of a rigid basement block within a collision zone. Tectonophysics, 366, 223-239.

Banks, C. J., Robinson, A. G. \& Williams, M. P. 1997. Structure and regional tectonics of the Achara-Trialet fold belt and the adjacent Rioni and Kartli foreland basins, Republic of Georgia. American Association of Petroleum Geologists, Memoir, 68, 331-346.

Barazangi, M., Sandvol, E. \& Seber, D. 2006. Structure and tectonic evolution of the Anatolian plateau in eastern Turkey. Geological Society of America Special Paper, 409, 463-473.

BARrier, E. \& VRIELYNCK, B. (Contributors: Bergerat, F., Brunet, M.-F., Mosar, J., Poisson, A. \& Sosson, M.) 2008. Palaeotectonic Maps of the Middle East. Tectonono-Sedimentary - Palinspastic Maps from Late Norian to Pliocene. Publisher CGMW, Paris, http://www.ccgm.org. Atlas of 14 maps, scale $1 / 18500000$.

Berberian, M. 1983. The Southern Caspian: a compressional depression floored by a trapped modified oceanic crust. Canadian Journal of Earth Sciences, 287, 177-196.

BRoD, I. A. 1962. Structural-Geomorphological Investigations in the Caspian Region. (Strukturno-geomorfologicheskie issledovaniva $v$ Prikaspii). Akademia NAUK SSSR, Sb. mat. Kompl. Yuzhnoi Geol. Eksped, 7 ray 8, Leningrad.

Brunet, M.-F., Korotaev, M. V., Ershov, A. V. \& Nikishin, A. M. 2003. The South Caspian Basin: a review of its evolution from subsidence modelling. Sedimentary Geology, 156, 119-148.

Budagov, B. A. 1963. Neotectonic movements near the Shakhdag Massif (Southeatern Caucasus) reinterpreted after the discovery of Late Sarmatian fossils. Doklady Akademii Nauk Azerbajdzanskoj SSR, 155, 30-32.

Budagov, B. A. 1969. Geomorphology of the Southern Slope of the Bolshoi Caucasus (Azerbaidzhan). (Geomorfologiya yuzhnogo sklona bolshogo Kavkaza). Akademia NAUK Republic Azerbaijan SSR, Baku.

BudAGOv, B. A. 1973. Geomorphology and Latest Tectonics of the South-Eastern Caucasus. (Geomorfologiya $i$ noveishaya tektonika yugo-vostochnogo Kavkaza). Akademia NAUK Republic Azerbaijan SSR, Baku.

Burbank, D. W. \& Anderson, R. S. 2001. Tectonic Geomorphology. Blackwell Science, Malden, MA.

Chalot-Prat, F., Tikhomirov, P. \& Saintot, A. 2007. Late Devonian and Triassic basalts from the southern continental margin of the East European Platform, tracers of a single heterogeneous lithospheric mantle source. Journal of Earth System Science, 116, 469-495.

Chernyshev, I. V., Lebedev, V. A. \& Arakelyants, M. M. 2006. K-Ar dating of Quaternary volcanics: methodology and interpretation of results. Petrology, 14, 62-80.

Cloetingh, S. A. P. L., Ziegler, P. A. et AL. 2007. 4-D topographic evolution of the intra-plate regions of
Europe: a multidisciplinary approach linking geology, geophysics and geotechnology. Global and Planetary Change, 58, 1-118.

Copley, A. \& JACKSON, J. 2006. Active tectonics of the Turkish-Iranian Plateau. Tectonics, 25, doi: 10.1029/ 2005 TC001906.

Daukeev, S. Z., UzhKenov, B. S. et AL. 2002. Atlas of Lithology-Paleogeographical, Structural, Palinspastic and Geoenvironmental Maps of Central Asia. Scientific Research Institute of Natural Resources YUGGEO, Almaty (Kazakhstan).

Delcaillau, B. 2004. Reliefs et tectonique récente. Vuibert, Paris

Djavadova, A. \& Mamula, N. 1999. Petroleum geology of the 'Akstafa Block' and surrounding KuraGabirry interfluve, Azerbaijan. Frontera Resources, Houston, 80.

DotduyeV, S. I. 1986. Nappe Structure of the Greater Caucasus Range. Geotectonics, 20, 420-430.

Egan, S. A., Mosar, J., Brunet, M.-F. \& Kangarli, T. 2009. Subsidence and uplift mechanisms within the South Caspian Basin: insights from the onshore and offshore Azerbaijan region. In: BRUneT, M.-F., Wilmsen, M. \& Granath, J. W. (eds) South Caspian to Central Iran Basins. Geological Society, London, Special Publications, 312, 219-240.

Ershov, A. V., Brunet, M.-F., Korotaev, M. V., Nikishin, A. M. \& Bolotov, S. N. 1999. Late Cenozoic burial history and dynamics of the Northern Caucasus molasse basin: implications for the foreland basin modelling. Tectonophysics, 313, 219-241.

Ershov, A. V., Brunet, M.-F., Nikishin, A. M., Bolotov, S. N., Nazarevich, B. P. \& Korotaev, M. V. 2003. Northern Caucasus basin: thermal history and synthesis of subsidence models. Sedimentary Geology, 156, 95-118.

Ershov, A. V., Nikishin, A. M., Bolotov, S. N. \& Korotaev, M. V. 2005. Mesozoic-Cenozoic subsidence evolution and geodynamics of the Caucasus. In: Geokart-Geos (ed.) 400 Million Years of Geological History of the Southern Part of Eastern Europe, 1, Moscow, 259-311.

Gamkrelidze, I. P. 1986. Geodynamic evolution of the Caucasus and adjacent areas in Alpine time. Tectonophysics, 127, 261-277.

GAMKRELIDZE, I. P. 1991. Tectonic nappes and horizontal layering of the Earth's crust in the Mediterranean belt (Carpathians, Balkanides and Caucasus). Tectonophysics, 196, 385-396.

Gamkrelidze, I. P. 1997. Terranes of the Caucasus and adjacent areas. Bulletin of the Georgian Academy of Sciences, 155, 291-294.

Gamkrelidze, I. P. \& Kuloshvili, S. 1998. Stress vector orientations and movement of the earth's crust of the territory of Georgia on the neotectonic stage. Bulletin of the Georgian Academy of Sciences, 158, 283-287.

Gamkrelidze, I. P. \& Shengelia, D. M. 2005. Precambrian-Paleozoic Regional Metamorphism, Granitoid Magmatism and Geodynamics of the Caucasus. Scientific World, Moscow.

Gamkrelidze, P. D. \& Gamkrelidze, I. P. 1977. The Nappes of the Southern Slope of the Great Caucasus (in the limits of Georgia). Metsniereba, Tbilisi. 
Gamkrelidze, P. D. \& Rubinstein, M. M. 1974. Problems of the Geology of Adzharo-Trialetia (Problemy geologii Adzharo-Trialetii). Metsniereba, Tbilisi.

Gazis, C. A., Lanphere, M., Taylor, H. P. \& Gurbanov, A. G. $1995 .{ }^{40} \mathrm{Ar} /{ }^{39} \mathrm{Ar}$ and ${ }^{18} \mathrm{O} /{ }^{16} \mathrm{O}$ studies of the Chegem ash-flow caldera and the Eldjurta Granite: Cooling of two late Pliocene igneous bodies in the Greater Caucasus Mountains, Russia. Earth and Planetary Science Letters, 134, 377-391.

Gudjabidze, G. E. 2003. Geological Map of Georgia 1:500 000. In: GAMkrelidze, I. P. (ed.) Georgian State Department of Geology and National Oil Company 'Saknatobi', Tbilisi.

Guliyev, I. S., Levin, L. E. \& Fedorov, D. L. 2003. Hydrocarbons Potential of the Caspian Region (System Analysis). Publishing House, Nafta Press, Baku.

Hafkenscheid, E., Wortel, M. J. R. \& Spakman, W. 2006. Subduction history of the Tethyan region derived from seismic tomography and tectonic reconstructions. Journal of Geophysical Research B, Solid Earth and Planets, 111(B08401), doi: 10.1029/ 2005JB003791.

Hess, J. C., Lippolt, H. J., Gurbanov, A. G. \& Michalski, I. 1993. The cooling history of the late Pliocene Eldzhurtinskiy granite (Caucasus Russia) and the thermochronological potential of grain-size/ age relationships. Earth and Planetary Science Letters, 117, 393-406.

Ismail-Zade, T. A., Gadjiev, T. G., Guseinov, A. N., Akhmedov, A. M. \& Yusufzade, H. B. 1987. Atla of Oil and Gas Bearing and Perspective Structures of Azerbaijan. USSR Ministry of Geology.

Jackson, J., Priestley, K., Allen, M. \& Berberian, M. 2002. Active tectonics of the South Caspian Basin. Geophysical Journal International, 148, 214-245.

JACKSON, J. A. 1992. Partitioning of strike-slip and convergent motion between Eurasia and Arabia in Eastern Turkey and the Caucasus. Journal of Geophysical Research, 97, 12 471-12479.

Kadirov, F., Mammadov, S., Reilinger, R. \& MCClusky, S. 2008. Some new data on modern tectonic deformation and active faulting in Azarbaijan (according to global positioning system measurements). Azerbaijan National Academy of Sciences Proceedings the Sciences of Earth, 1, 82-88.

KANGaRLI, T. 1982. Geological structures in the Azerbaijan lateral crest of the High Caucasus. Unpublished $\mathrm{PhD}$ thesis, Azerbaijan State University.

Kangarli, T. 2005. Greater Caucasus. In: Khain, V. E. \& AlizadeH, A. A. (eds) Geology of Azerbaijan, Tectonics, IV. Nafta-Press, Baku, Azerbaijan, 43-213.

Kazmin, V. G. 2006. Tectonic evolution of the Caucasus and Fore-Caucasus in the Late Paleozoic. Doklady Earth Sciences, 406, 1-3.

Kazmin, V. G. \& Tikhonova, N. F. 2006. Late Cretaceous-Eocene marginal Seas in the Black-SeaCaspian Region: Paleotectonic reconstructions. Geotectonics, 40, 162-182.

Keller, E. A. \& Pinter, N. 2002. Active Tectonics Earthquakes, Uplift, and Landscape. Prentice Hall, Upper Saddle River.

KHaIN, V. E. 1975. Structure and main stages in the tectono-magmatic development of the Caucasus: an attempt at geodynamic interpretation. American Journal of Science, 275-A, 131-156.

KhaIN, V. E. 1997. Azerbaijan - Greater Caucasus. In MoOres, E. M. \& FAIRBridge, R. W. (eds) Encyclopedia of European and Asian Regional Geology. Chapman and Hall, London, 60-63.

Knapp, C. C., KnapP, J. H. \& Connor, J. A. 2004 Crustal-scale structure of the South Caspian Basin revealed by deep seismic reflection profiling. Marine and Petroleum Geology, 21, 1073-1081.

Koçyigit, A., Yilmaz, A., Adamia, S. A. \& Kuloshvili, S. 2001. Neotectonics of the East Anatolian Plateau (Turkey) and Lesser Caucasus: implication for transition from thrusting to strike-slip faulting. Geodynamica Acta, 14, 177-195.

Kokolashvili, I. \& Shatilova, I. 2009. The preliminary results of palynological investigations of lower Sarmatian deposits of Kakheti. Proceedings of the Georgian Academy of Sciences, Biological Series, B, 7, 85-89.

Kopp, M. L. \& Shcherba, I. G. 1985. Late Alpine development of the East great Caucasus. Geotectonics, 19, 497-507.

Kovachev, S. A., Kaz'min, V. G., Kuzin, I. P. \& LoBKovsky, L. I. 2006. New data on seismicity of the Middle Caspian basin and their possible tectonic interpretation. Geotectonics, 40, 367-376.

Kral, J. \& Gurbanov, A. G. 1996. Apatite fission track data from the Great Caucasus pre-alpine basement. Chemie der Erde, 56, 177-192.

Krasnov, I. I., Duphorn, K. \& Voges, A. 1974. International Quaternary map of Europe - 12 Tbilisi. In International Ouaternary map of Europe. Bundesanstalt für Bodenforschung/UNESCO, Berlin.

LeBedEv, V. A. 2005. Chronology of magmatic activity of the Elbrus volcano (Greater Caucasus): evidence from K-Ar Isotope dating of lavas. Doklady Earth Sciences, 405A, 1321-1326.

Lebedev, V. A. \& Bubnov, S. N. 2006. Pliocene granitoid massif in the Kazbek volcanic center: first geochronological and isotope-geochemical data. Doklady Earth Sciences, 411A, 1393-1397.

Lordkipanidze, D., Jashashvili, T. ET AL. 2007. Postcranial evidence from early Homo from Dmanisi, Georgia. Nature, 449, 305-310.

Lukina, N. V. 1981. The age of the river terraces in the central Caucasian foreland. Geomorfologia, 2, 68-75.

Mamedov, A. V. 1997. The Late Pleistocene-Holocene history of the Caspian Sea. Quaternary International, 41/42, 161-166.

Mangino, S. \& Priestley, K. 1998. The crustal structure of the southern Caspian region. Geophysical Journal International, 133, 630-648.

McClusky, S., Balassanian, S. ET aL. 2000. Global positioning system constraints on plate kinematics and dynamics in the eastern Mediterranean and Caucasus. Journal of Geophysical Research, Solid Earth, 105, 5695-5719.

Mengel, K., Borsuk, A. M., Gurbanov, A. G., WedePOHL, K. H., BaumanN, A. \& Hoefs, J. 1987. Origin of spillitic rocks from the southern slope of the Greater Caucasus. Lithos, 20, 115-123.

Mikhailov, V., Panina, L. V., Polino, R., Koronovsky, N. V., Kiseleva, E. A., Klavdieva, N. V. \& 
Smolyaninova, E. I. 1999. Evolution of the North Caucasus foredeep: constraints based on the analysis of subsidence curves. Tectonophysics, 307, 361-379.

Mitchell, J. \& Westaway, R. 1999. Chronology of Neogen and Quaternary uplift and magmatism in the Caucasus: constraints from $\mathrm{K}-\mathrm{Ar}$ dating of volcanism in Armenia. Tectonophysics, 304, 157-186.

Morton, A., Allen, M. et AL. 2003. Provenance patterns in a neotectonic basin: Pliocene and Quaternary sediment supply to the South Caspian. Basin Research, 15, 321-337.

Mustafayev, M. A. 2001. Petrology and geodynamic conditions of formation of the early Alpine stage magmatic series of the East Caucasus, Azerbaijan. In: 4th International Symposium on Eastern Mediterranean Geology Proceedings. Isparta, Turkey, $165-178$.

NARImanov, N. P. 1992. Tectonic regionalization of offshore of South Caspian depression. Geologiya Nefti $i$ Gaza, 11, 22-24.

Nikishin, A. M., Brunet, M.-F., Cloetingh, S. \& Ershov, A. V. 1997. Northern Peri-Tethyan Cenozoic intraplate deformations: influence of the Tethyan collision belt on the Eurasian continent from Paris to Tian-Shan. Comptes Rendus de l'Académie des Sciences de Paris, Série II, 324, 49-57.

Nikishin, A. M., Cloetingh, S., Brunet, M.-F., Stephenson, R. A., Bolotov, S. N. \& Ershov, A. V. 1998. Scythian platform, Caucasus and Black sea region: Mesozoic-Cenozoic tectonic history and dynamics. In: Crasouin, S. \& Barrier, E. (eds) Peri-Tethys Memoir 3: Stratigraphy and Evolution of Peri-Tethyan Platforms. Mémoires du Muséum national d'Histoire naturelle, Paris, 177, 163-176.

Nikishin, A. M., Korotaev, M. V., Ershov, A. V. \& BRUnet, M.-F. 2003. The Black Sea basin: tectonic history and Neogene-Quaternary rapid subsidence modelling. Sedimentary Geology, 156, 149-168.

Nikishin, A. M., Ziegler, P. ET AL. 2001. Mesozoic and Cainozoic evolution of the Scythian Platform Black Sea - Caucasus domain. In: Ziegler, P. Cavazza, W., Robertson, A. H. F. \& CrasquinSoleau, S. (eds) Peri-Tethys Memoir 6: Peri-Tethyan Rift/Wrench Basins and Passive Margins. Mémoires du Muséum national d'Histoire naturelle, Paris, 186 295-346.

Nilforoushan, F., Masson, F. et al. 2003. GPS network monitors the arabia-Eurasia collision deformation in Iran. Journal of Geodesy, 77, 411-422.

Nosova, A. A., Sazonova, L. V., Dokuchaev, A. Y. Grekov, I. I. \& Gurbanov, A. G. 2005. Neogen Late-collisional subalkaline granitoids in the area of Mineral'nye Vody, Caucasus: T-P-fo crystallization conditions, fractional and fluid-magmatic differentiation. Petrology, 13, 122-160.

Philip, H., Cisternas, A., Gvishiani, A. \& Gorshkov, A. 1989. The Caucasus: an actual example of the initial stages of continental collision. Tectonophysics, 161, 1-21.

Popov, S. V., Rögl, F. R. A. Y., Steininger, F. F. Shcherba, I. G. \& Kovac, M. 2004. LithologicalPaleogeographic maps of Paratethys. 10 maps Late Eocene to Pliocene. Courier Forschungsinstitut Senckenberg, 250, 46.
Priestley, K., Baker, C. \& Jackson, J. 1994. Implications of earthquake focal mechanism data for the active tectonics of the south Caspian Basin and surrounding regions. Geophysical Journal International, 118, $111-141$.

Rastyorova, V. A. \& Shcherbakova, E. M. 1967. The uplift of the central Caucasus during late-glacial times. In: Gerasimov, I. P. (ed.) Recent Crustal Movements. Israel Program Science Translation, 318-326.

Rebaï, S., Philip, H., Dorbath, L., Borissoff, B., Haessler, H. \& Cisternas, A. 1993. Active tectonics in the Lesser Caucasus: coexistence of compressive and extensional structures. Tectonics, 12, 1089-1114.

ReIlinger, R., MCClusky, S. ET AL. 2006. GPS constraints on continental deformation in the Africa-Arabia-Eurasia continental collision zone and implications for the dynamics of plate interactions. Journal of Geophysical Research B, Solid Earth and Planets, 111, doi: 10.1029/2005JB004051.

Reynolds, A. D., Simmons, M. D. et aL. 1998. Implications of outcrop geology for reservoirs in the Neogene productive series: Apsheron Peninsula, Azerbaijan. AAPG Bulletin, 82, 25-49.

Rogozin, E. A. \& Ovsyuchenko, A. N. 2005. Seismic and geological activity of tectonically faulted structures in the Northern Caucasus. Physics of Solid Earth, 41, 449-461.

Rogozin, E. A., Yunga, S. L., Marakhanov, A. V., Ushanova, E. A., OvSYUChenKo, A. N. \& Dvoretskaya, N. A. 2002. Seismic and tectonic activity of faults on the south slope of the NW Caucasus. Russian Journal of Earth Sciences, 4, 233-241.

Saintot, A. \& Angelier, J. 2000. Plio-Quaternary paleostress regimes and relation to structural development in the Kertch-Taman peninsulas (Ukraine and Russia). Journal of Structural Geology, 22, 1049-1064.

Saintot, A., Angelier, J., Ilyn, A. \& Goushtchenko, O. 1998. Reconstruction of paleostress fields in Crimea and the NW Caucasus, relationship with major structures. Mémoires du Muséum national d'Histoire naturelle, Paris, 177, 89-112.

Saintot, A., Brunet, M.-F. et AL. 2006a. The MesozoicCenozoic tectonic evolution of the Greater Caucasus. In: Gee, D. G. \& Stephenson, R. A. (eds) European Lithosphere Dynamics. Geological Society, London, Memoirs, 32, 277-289.

Saintot, A., Stephenson, R. A., Stovba, S., Brunet, M.-F., Yegorova, T. P. \& Starostenko, V. $2006 b$. The evolution of the southern margin of Eastern Europe (Eastern European and Scythian platforms) from the latest Precambrian-Early Paleozoic to Early Cretaceous. In: GeE, D. G. \& Stephenson, R. A. (eds) European Lithosphere Dynamics. Geological Society, London, Memoirs, 32, 481-505.

Shatilova, I., Maissuradze, L., Koiava, K., McheDlishvili, N., Rukhadze, L., Spezzaferri, S. \& Strasser, A. 2008. Foraminifers and palynomorphs in the Sarmatian deposits of Kartli (Eastern Georgia): stratigraphical and palaeoclimatological implications. Proceedings Georgian Academy of Science, Biology Series. B, 8, 65-76. 
Shatilova, I. I. 1992. The late Cenozoic climate and vegetation of western Georgia. Paleontologia I Evolucio, 24-25, 465-481.

Shcherbakova, E. M. 1973. The Ancient Glaciation of the Great Caucasus. (Drevnee oledenenie Bolshogo Kavkaza). Moscow University Press, Moscow.

Shikalibeily, E. S. \& Grigoriants, B. V. 1980. Principal features of the crustal structure of the South-Caspian Basin and the conditions of its formation. Tectonophysics, 69, 113-121.

SHIRINov, N. S. 1973. Geomorphological Structure of the Kura-Araksa Depression (Geomorfologicheskoe stroenie Kura-Araksinskoi depressii). Akademia NAUK Republic Azerbaijan SSR, Baku.

SHIRINOv, N. S. 1975. Latest Tectonics and Development of the Relief of the Kura-Araska Depression (Noveishaya tektonika $i$ razvitie relyefa KuraAraksin-skoi depressii). Akademia NAUK Republic Azerbaijan SSR, Baku.

SHOLPO, V. N. 1993. Strucure of inversion anticlinoria in the core of the Greater Caucasus: an advection hypothesis. Geotectonics, 23, 245-251.

SoborNov, K. O. 1994. Structure and petroleum potential of the Dagestan thrust belt, northeastern Caucasus, Russia. Bulletin of Canadian Petroleum Geology, $\mathbf{4 2}$ $352-364$.

SoborNov, K. O. 1996. Lateral variations in structural styles of tectonic wedging in the northeastern Caucasus, Russia. Bulletin of Canadian Petroleum Geology, 44, 385-399.

Somin, M. L., Kotov, A. B., Sal'nikova, E. B. Levchenko, O. A., Pis'mennyi, A. N. \& Yakovlev, S. Z. 2006. Paleozoic rocks in infrastructure of the metamorphic core, the Greater Caucasus Main Range Zone. Stratigraphy and Geological Correlation, 14, 475-485.

Sosson, M., Rolland, Y. et al. 2010. Subductions, obduction and collision in the Lesser Caucasus
(Armenia, Azerbaijan, Georgia), new insights. In: Sosson, M., KaYmakci, N., Stephenson, R. A., Bergerat, F. \& Starostenko, V. (eds) Sedimentary Basin Tectonics from the Black Sea and Caucasus to the Arabian Platform. Geological Society, London, Special Publications, 340, 329-352.

Stampfli, G. M., Borel, G., Cavazza, W., Mosar, J. \& ZIEGLER, P. 2001. Palaeotectonic and palaeogeographic evolution of the western Tethys and PeriTethyan domain. Episodes, 24, 222-228.

Tan, O. \& Taymaz, T. 2006. Active tectonics of the Caucasus: Earthquake source mechanisms and rupture histories obtained from inversion of teleseismic body waves. Geological Society of America, Special Paper, 409, 531-578.

Triep, E. G., Abers, G. A., Lerner-Lam, A. L., MishtaKin, V., Zakharchenko, N. \& Starovolt, O. 1995. Active thrust front of the Greater Caucasus: the April 29, 1991, Racha earthquake sequence and its tectonic implications. Journal of Geophysical Research, 100, 4011-4033.

Ulmishek, G. F. 2001. Petroleum geology and resources of the Middle Caspian Basin, former Soviet Union. U.S. Geological Survey Bulletin, 2201-A, 38.

Vernant, P., Nilforoushan, F. et al. 2004. Present-day crustal deformation and plate kinematics in the Middle East constrained by GPS measurements in Iran and northern Oman. Geophysical Journal International, 157, 381-398.

Vincent, S. J., Morton, A. C., Carter, A., Gibis, S. \& Barabadze, T. G. 2007. Oligocene uplift of the western Greater Caucasus: an effect of initial ArabiaEurasia collision. Terra Nova, 19, 160-166.

Zonenshain, L. P., KuZmin, M. I. \& Natapov, L. M. 1990. Geology of the USSR: A Plate Tectonic Synthesis. American Geophysical Society, Washington. 